Gimousias, P. (2020). The concept of an effective \& Education teacher through the eyes of greek teachers and students: a literature review. Social Work and Education. Vol. 7, No. 3. Ternopil-Aberdeen, 2020. pp. 315-324. DOI:

๑ SW\&E, 2020

UDC 378.1 10.25128/2520-6230.20.3.6.

DOI: $10.25128 / 2520-6230.20 .3 .6$.

\title{
THE CONCEPT OF AN
} EFFECTIVE TEACHER THROUGH THE EYES OF GREEK TEACHERS AND STUDENTS: A LITERATURE REVIEW

Prokopis Gimousias,

PhD student, Greece

gimousias@gmail.com

\section{Article history:}

Received: June 15, 2020

1st Revision: July 26, 2020

Accepted: September 30, 2020
Abstract. In recent years there has been increasing interest on the identification of the characteristics of an 'effective' teacher within an 'effective' school, where school leakage will be minimal and academic success given. Law 1566 of 1985 defines the purpose of primary and secondary education as follows: The purpose of primary and secondary education is to contribute to the comprehensive, harmonious and balanced development of the students' mental and psychosomatic powers so that, regardless of their origin, the opportunity to become integrated personalities and to live creatively. The present paper analyzes the basic characteristics of an effective teacher through the eyes of Greek teachers and students.

Key words: effective teacher; effective school; interpersonal relationships; effectiveness; pedagogy. 


\section{Introduction}

In modern teaching and pedagogy, the concept of a good teacher is often identified with that of an effective teacher. Effectiveness mainly refers to the results of the teaching effort and is therefore considered more objective than that of the good teacher. Then, the term "effective" is used as we often find it in the literature. But when it comes to the research done, we prefer the characterization of "good" or "better" as it is the subjective opinion of each student that we tested in our research. The need to evaluate the teacher and the quality of education has resulted in research being conducted to identify the characteristics of an effective teacher. Such surveys have been conducted in Greece since 1990 and onwards (Davidson, Major \& Michaelsen, 2014), but research in this direction has not established how effective the teacher is, neither did the institutions for the evaluation of the educational project (Galassi, 2017).

Ajayi (2014) describes ten types of behavior to define the concept of the teacher that refer to the teacher's effectiveness. He distinguishes them in basic types of behavior (clarity, diversity, task commitment, involvement in the learning process and moderate to high successful students) and in catalytic behaviors (teacher use of ideas, lesson structure, technique of learning) questions, encouraging students and excitement). Other researchers (Harris, 2019) propose a teacher evaluation system based on observation of teaching giving five key observation axes: teaching techniques, course of teaching and the way of presenting the material, organization and management of the classroom, the learning environment and the communication climate of the classroom, the professional development and the responsibility of the teachers. Kyrgiridis et al., (2014) research combines the characteristics of an effective teacher as follows: a) systematic b) friendly c) capable of oral communication d) enthusiastic e) personalizes teaching and f) is able to educationally use and utilize modern technological tools. According to Coe et al., (2014), the best teachers do not just focus on what students should learn, or how they will teach the lesson, but give equal weight to how they will enhance the learning process.

Banks \& Banks (2019) defined the seven principles of effective teaching as part of the research conducted by the American Association of Higher Education (AAHE). After fifty years of research data collection, it has finally come to the definition of the seven principles of an effective teacher, which are: encouraging students to contact with the teacher, encouraging student collaboration, encouraging active learning, providing immediate feedback to students, inspiring high expectations of their students, and finally respecting students' diverse talents and ways of learning (Caboni, Mundy \& Duesterhaus, 2014). As Dimitrov (2014) points out, these seven principles offer an important breakthrough for effective teaching and emphasize student-teacher interaction.

As it turned out, the definition of a good teacher and the description of his/her abilities and characteristics that lead to effective teaching have been the subject of much 
research. At the same time various theoretical approaches, mainly to the sciences we call "human sciences", have provided the theoretical framework for supporting various research hypotheses. In the following we will discuss the theoretical approaches to pedagogical psychology and how they interpret the role of the teacher, describing in particular the views of the representative of C. Rogers' humanitarian approach. Finally, we will describe the characteristics of an effective teacher through the results of studies that were based on teacher and student judgments.

\section{Literature review}

\section{Research data on the definition of the concept of an effective teacher in teachers' views}

Many researchers have repeatedly sought to define those characteristics of the attitudes and behaviors of teachers that constitute effective teaching and distinguish the effective teacher. This goal is not easy as there are conflicting values, different theoretical and methodological approaches to the subject and at the same time there are many sources of relevant information (Little, Akin-Little \& O' Neill, 2015). One source of research data is teachers themselves in self-reports and when they express judgment about colleagues. A second source of data to characterize the effective teacher is students as they have direct access to what teachers in the classroom do (Hills, 2018). We will try to record the characteristics of the good teacher as they are evaluated and described by the teachers themselves.

Special reference is made to surveys in which students describe the characteristics of a good teacher as our research examines the concept of a good teacher through students' judgments.

Teachers' judgments of the characteristics of the effective teacher have been the subject of much research. Moreland \& Levine (2014) collected research results that linked teachers' personality traits to effective teaching. In order to process the results, he/she divided the research into three categories: those with teacher-to-peer descriptions, those with teacher self-reports, and finally student-based surveys. Research has shown that teachers, when described by their peers, regard the personality traits that describe the teacher as social and enthusiastic, supportive in their relationships with others, highly self-esteem, flexible, emotionally stable, friendly and responsible, associated with the effectiveness of teachers. Whereas when research is based on teachers' self-reports, the above personality traits are not linked to effective teaching. This is because, as shown in the research by Moreland \& Levine (2014), when teachers are asked to judge their self-efficacy they focus on students rather than on their own personality traits.

Similar investigations were also carried out in Greece. The first survey of teachers' self-concept was conducted in primary and secondary teachers. Teachers who participated in Professor Xochellis' (2016) research believe that their work is a common 
pedagogical mission and a function of their pedagogical and psychological education. Although they feel insecure in their work, they are generally satisfied with their profession, which they see primarily as a contribution to the shaping of the younger generation, and think they have moderate authority in society.

They also believe that their studies have proved useful for their work, especially their pedagogical studies and, above all, their internships." According to the same research, "primary education representatives perceive the teacher's work primarily as a pedagogical mission, whereas for most secondary education representatives the role of the specialized teacher-scientist is paramount" (p. 28). -29).

The second research was conducted by Shafto, Goodman \& Griffiths (2014). Secondary school teachers were asked to answer two closed questions. Each question described seven characteristics that teachers had to prioritize in order of importance. The first question was, "What do you think is bothering your students about a teacher's behavior?" The answers given in order of importance were: to discriminate students in the classroom, to humiliate and offend students, to refuse to listen to the students opinion, to not be imposed in the classroom, to teach only with good students, not having enough knowledge, being authoritarian. The second question that secondary school teachers were asked to answer was: "What do you think will please students in a teacher's behavior?" The answers in order of importance were: to encourage students in their endeavors, to understand the lesson, to discuss with their students the topics of interest to them, to have humor, to calculate their students' opinion, helping those with learning disabilities, spending time without a lesson.

Teachers, when asked to express their views on good teacher characteristics and effective teaching, often raise the issue of their education in the pedagogical schools. In many of these schools the pedagogical courses are scarce and voluntary and there is a lack of sufficient practical training. Teachers report that in order to pursue their profession they have resorted to their own memories, or to information gained from their colleagues with experience (Fensham, 2018). In addition, teachers emphasize the need for systematic training and the support structures that will support their work.

\section{The concept of a 'good teacher' through students' judgments}

Interpersonal communication and students' interaction with teachers, as well as the concept of a 'good teacher' model for students are issues that have occasionally aroused the research interest of education scholars. The stereotype that emerges from these studies of students' perception of the effective teacher' is that the teacher must be: rigorous and fair, clear and interesting, pleasant and understanding (Konings et al., 2014).

Students have been overestimated and sometimes overlooked as a source of information for evaluating teachers and their work. The subject has been of interest to researchers from a long time who have dealt with factors that may influence students' 
assessments. A review of research studies shows that different forms of assessment lead to different directions and judgments regarding effective teacher. Student evaluation is usually associated with learning, when the learning outcomes are positive and the rating is high. Fauth et al., (2014) collected 75 years of research data in order to investigate the validity and reliability of teacher evaluations by their students. Among his/her other notes that mainly concern students 'prejudices related to their previous experience, the time the lesson is taught, the teacher's expected grade, and the type of lesson as a parameter that influences students' ratings. In particular, the courses in the humanities are rated higher than those in the natural sciences and technical subjects.

Next, we will talk about some research in which students define the characteristics of an effective teacher, either as an ideal model or as describing the best teacher in their school life. In Fook (2015) study, students describe teachers who made a difference in their lives and consider them important. Students describe these teachers as allies and experts. An educator is considered effective when he/she / she combines having something important to say, while being open, genuine, and honest with his/her or her students. After studying hundreds of questionnaires and episodes during the course, it was concluded that, regardless of age, culture, and personal characteristics, students describe two general sets of characteristics of an effective teacher: reliability and authenticity.

Reliability, according to Brookfield's analysis, is a concept defined by students as feeling that the teacher has something important to say or offer and whatever that is (skills, knowledge, inspiration, wisdom, information) it will be useful for them to learn. Reliable teachers seem to have a breadth of knowledge, intuition, wisdom, experience that transcends students' knowledge. The same researcher refers to the indicators that determine reliability, as they emerged from his/her research and always in accordance with students' judgments (Lundgren \& Poell, 2016):

- Specialization. The management of the competences and skills that the teacher is going to transfer to his/her students. He/she knows what to do, he/she has clear knowledge. He/she gives the impression of an expert. Can handle unexpected events and questions with confidence.

- The experience. Students appreciate the teacher's experience in the subject he/she is teaching. The fact that their teachers' judgment is based on previous experience is appreciated, while at the same time they are able to organize their activities based on that experience.

- Intelligence and logic. The ability of the teacher to explain the conclusions, the lesson plan and the evaluation methods.

- Confidence and certainty. The ability to provide feedback and the assurance that the students understood the right thing.

Authenticity, on the other hand, is defined by students as the feeling that the teacher is open and honest and tries to help his/her students learn. Teachers with authenticity 
attributes are not sneaky, they do not have "hidden papers" and thus gain the confidence of their students.

At the same time, they are people with flesh and bones, with excitement, weaknesses, emotions. They do not hide behind behaviors that are considered appropriate for the title of professor. As Owen (2014) report, genuine teachers strive to do what is good for their students in any environment and in any context and are perceived as such by their students. Students consider that teachers who are their allies in learning are genuine, can trust them, are open and honest in negotiating, who care about how their students feel and focus on achieving the learning goals of the educational practice. According to Mentzer, Becker \& Sutton (2015), authenticity is about teaching who you are. Beres \& Fook (2019) also defined the authenticity indicators which are: consent and consistency. it is about the consistency of words and deeds, full disclosure. making the criteria, expectations and goals of each action known in the educational process from the outset. knowing all this is important for building trust relationships, sensitivity and responsibility. trying to help students with what they know, what they want to learn and what students expect from the lesson, humanity. teachers are people with flesh and bones, with enthusiasm who report autobiographical events and recognize difficulties. Grouping the dimensions of effective teaching and the characteristics of good teachers, as defined in relevant student surveys, has been the subject of some of the studies that we will mention below.

Kuczynski, Parkin \& Pitman (2014) study is a systematic synthesis of research conducted primarily by students in colleges in South America and Canada. The research review evaluates students' views of teaching in relation to habits, behaviors, and educational practices. The studies that were collected were categorized into three types: (a) studies in which students describe the ideal teacher; (b) studies in which students define the characteristics they consider particularly important for teaching; and (c) studies in which students describe the best teacher they've ever had.

The features described as important are nineteen: raising the interest, the excitement of the subject being taught, the knowledge of the subject, the preparation and organization of the lesson, the clarity and understanding of teaching, the ability of oral speech, the sensitivity and interest regarding the learning level of the classroom and progress achieved, clarity in subject matters and requirements, nature and value of educational material, nature and usefulness of supplementary materials and aids, teaching lesson (and size of study material), impartiality, managing classroom difficulties, quality and frequency of feedback to students, encouraging questions and discussion, thought provoking, encouraging free thinking, interest and students' respect and friendliness, availability and supportive attitude.

The classification of the characteristics varies according to the type of surveys mentioned above and the type of questions, i.e. whether the questions were closed or open. The researcher Kobavashi, Zappa-Hollman \& Duff (2017) after applying factor 
analysis identified three structures grouping the characteristics mentioned above. These three structures are: (a) presentation of material, (b) facilitating learning, and (c) regulating learning. The presentation of the material constitutes the teacher's work as the presenter of the subject, in the role of the acting person or the conveyor of knowledge. It includes features such as course organization, knowledge of the subject, and interest. The second set of traits (facilitating learning) includes traits such as friendly attitude, interest and respect for students, availability and supportive attitude. When students answer open-ended questions, the characteristics of this group are first ranked in describing both the ideal and the best teacher in their school life. The third group described as learning regulation includes the teacher's activities as an administrator of classroom problems and the characteristic of impartiality.

Similar results were also given by Benton \& Cashin (2014) study investigating the dimensions of educational effectiveness as distinguished in student evaluations from a collection of seventeen studies. The researchers tried to create a "common core" of factors. The analysis revealed four factors, three of which were strongly correlated. The three factors relate to the teacher and, in particular, to his/her role as a teacher, as a personality and as a regulator of everyday classroom situations. The fourth factor includes some general issues related to administrative competence, subject knowledge, selection of appropriate educational material.

Lyons \& Kuron (2014) in their research presented nine dimensions in the definition of a good teacher, after analyzing data they collected with a tool they designed to evaluate the educational work and, subsequently, the teachers by the students. The dimensions cited by Marsh are: student learning outcomes, teacher excitement, course organization, team members 'interactions, interpersonal relationships, students' sense of security, how they are tested and scored, the tasks assigned, the amount of work required. Lyons \& Kuron (2014) argues that student evaluation is the only indicator of how effective teaching is.

\section{Conclusions}

Describing and classifying the characteristics of an effective teacher is mainly a descending classification of competencies and behaviors that the research participants consider important. These features are usually grouped ex post. Indicatively we refer to the Brookfield grouping which speaks of two sets of competences and behaviors and integrates them into the concepts of authenticity and credibility, where authenticity refers to attitudes and behaviors in the teacher-student relationship and credibility refers to their role as transmitters, knowledge and topics that describe the knowledge of the subject, the organization of the lesson, the clear learning objectives. A similar grouping of features is also made by Kobayashi, Zappa-Hollman \& Duff (2017) with the structures of (a) presentation of material, (b) facilitating learning, and (c) regulating learning. 
Summarizing the results of the above surveys, we find that students evaluate positively both teacher personality traits and subject knowledge. The characteristics that determine a good teacher and define his/her role through teachers' views are related both to the pedagogical role of teachers and to their role as holders of knowledge they offer to their students. Specifically, the characteristics reported describe the teacher's pedagogical role on the one hand (encourages his/her students in their endeavors, discusses with their students the issues of interest to them, has humor, considers students' opinions, is capable of managing classroom problems, can control his/her own behavior) and his/her role as a specialist scientist (focuses on students, shows enthusiasm for teaching, uses appropriate teaching methods and knows the subject taught).

\section{References}

Ajayi, L. (2014). Investigating effective teaching methods for a place-based teacher preparation in a rural community. Educational Research for Policy and Practice, 13(3), 251-268.

Banks, J. A., \& Banks, C. A. M. (Eds.). (2019). Multicultural education: Issues and perspectives. John Wiley \& Sons.

Benton, S. L., \& Cashin, W. E. (2014). Student ratings of instruction in college and university courses. In Higher education: Handbook of theory and research (pp. 279326). Springer, Dordrecht.

Béres, L., \& Fook, J. (2019). Learning Critical Reflection: Experiences of the Transformative Learning Process. Routledge.

Caboni, T., Mundy, M., \& Duesterhaus, M. B. (2014). The implications of the norms of undergraduate college students for faculty enactment of principles of good practice in undergraduate education. In Influences on College Student Learning (pp. 129-141). Routledge.

Coe, R., Aloisi, C., Higgins, S., \& Major, L. E. (2014). What makes great teaching. Review of the underpinning research, 1-57.

Davidson, N., Major, C. H., \& Michaelsen, L. K. (2014). Small-group learning in higher education - cooperative, collaborative, problem-based, and team-based learning: an introduction by the guest editors. Journal on Excellence in College Teaching, 25(3\&4), 1-6.

Dimitrov, D. M. (2014). Statistical methods for validation of assessment scale data in counseling and related fields. John Wiley \& Sons.

Fauth, B., Decristan, J., Rieser, S., Klieme, E., \& Büttner, G. (2014). Student ratings of teaching quality in primary school: Dimensions and prediction of student outcomes. Learning and Instruction, 29, 1-9.

Fensham, P. (2018). Alienation from Schooling (1986). Routledge. 
Fook, J. (2015). Reflective practice and critical reflection. Handbook for practice learning in social work and social care: Knowledge and theory, 3.

Galassi, J. (2017). Strengths-based school counseling: Promoting student development and achievement. Routledge.

Harris, A. (2019). Teaching and learning in the effective school. Routledge.

Hills, P. J. (2018). The self-teaching process in higher education. Routledge.

Kobayashi, M., Zappa-Hollman, S., \& Duff, P. (2017). Academic discourse socialization. Language socialization, 8, 239-254.

Kuczynski, L., Parkin, C. M., \& Pitman, R. (2014). Socialization as Dynamic Process. Handbook of socialization: Theory and research, 135.

Kyrgiridis, P., Derri, V., Emmanouilidou, K., Chlapoutaki, E., \& Kioumourtzoglou, E. (2014). Development of a questionnaire for self-evaluation of teacher effectiveness in physical education (SETEQ-PE). Measurement in Physical Education and Exercise Science, 18(2), 73-90.

Little, S. G., Akin-Little, A., \& O'Neill, K. (2015). Group contingency interventions with children-1980-2010: A meta-analysis. Behavior Modification, 39(2), 322-341.

Lundgren, H., \& Poell, R. F. (2016). On critical reflection: A review of Mezirow's theory and its operationalization. Human Resource Development Review, 15(1), 3-28.

Lyons, S., \& Kuron, L. (2014). Generational differences in the workplace: A review of the evidence and directions for future research. Journal of Organizational Behavior, 35(S1), S139-S157.

Mentzer, N., Becker, K., \& Sutton, M. (2015). Engineering design thinking: High school students' performance and knowledge. Journal of Engineering Education, 104(4), 417-432.

Moreland, R. L., \& Levine, J. M. (2014). Socialization in organizations and work groups. In Groups at work (pp. 83-126). Psychology Press.

Owen, S. (2014). Teacher Professional Learning Communities: Going beyond Contrived Collegiality towards Challenging Debate and Collegial Learning and Professional Growth. Australian journal of adult learning, 54(2), 54-77.

Shafto, P., Goodman, N. D., \& Griffiths, T. L. (2014). A rational account of pedagogical reasoning: Teaching by, and learning from, examples. Cognitive psychology, 71, 55-89.

Xochellis, P. (2016) The teacher in the modern world: The role and the professional profile today, the education and the evaluation of his work. Athens: Typothito. 


\section{ЕФЕКТИВНИЙ ВЧИТЕЛЬ ОЧИМА ГРЕЦЬКИХ ПЕДАГОГІВ ТА УЧНІВ: ОГЛЯД ЛІТЕРАТУРИ}

Прокопіс Гімоусіас, аспірант Тернопільського національного педагогічного університету імені Володимира Гнатюка, giтоиsias@gmail.com

Анотація. Впродовж останніх років зростає інтерес до визначення характеристик "ефективного" вчителя в "ефективній" школі, які є важливим чинником зменшення відтоку учнів та покращення їх академічних досягнень. Чинне законодавство визначає мету початкової та середньої освіти як сприяння всебічному, гармонійному та збалансованому розвитку розумових та психосоматичних ресурсів учнів з метою ӥх становлення як иілісних особистостей, здатних творчо реалізувати свої здібності і жити повноцінним життям, незалежно від їх походження та інших чинників. Реалізація даного завдання значною мірою залежить від того, наскільки ефективно учителі виконують свою професійну діяльність. У даному дослідженні проаналізовано основні характеристики ефективного вчителя з точки зору грецьких учителів та учнів. Мета дослідження полягала у визначенні характеристик ефективного вчителя як їх розуміють ключові учасники навчального процесу - самі учителі та їх учні.

Теоретичною основою дослідження послужили фундаментальні положення педагогічної психології про роль учителя у навчальному прочесі та гуманістичної парадигми К. Роджерса про значення міжособистісної взаємодї у педагогічній діяльності. Для досягнення мети дослідження було здійснено огляд досліджень, в яких описуються характеристики, ставлення та поведінка, притаманні ефективному педагогу. Джерелом даних у проаналізованих дослідженнях були самі педагоги та учні.

Узагальнення результатів аналізу дозволяє констатувати, щзо більшість існуючих описів та класифікацій ефективного вчителя будуються на основі їх ранжування від більш важливих до менш важливих та описують здебільшого два види компетенцій, пов'язаних з автентичністю та довірою. Автентичність стосується ставлення та поведінки у відносинах вчитель-учень, а довіра - ї ролі як передавачів знань та характеризує знання предмету, вміння ставити навчальні цілі та досягати їх, організовувати діяльність учнів тощо. Встановлено, щзо для студентів важливими є як особистісні якості вчителя, так i знання ним предмета. Характеристики, щзо визначають хорошого вчителя з точки зору вчителів пов'язані як з їх педагогічною роллю (заохочує учнів у їхніх починаннях, обговорює з учнями ними цікаві для них питання, має почуття гумору, враховує думку учнів, здатний управляти проблемами в класі, може контролювати власну поведінку тощь), так $i$ з їхньою роллю носї̈ знань (зосереджується на освітніх потребах учнів, виявляє ентузіазм до викладання, використовує відповідні методи навчання, знає предмет, щзо викладає тощо).

Ключові слова: ефективний вчитель; ефективна икола; міжособистісні стосунки; ефективність; педагогіка. 